\title{
Opinion of family farmers on organic food supply to the Brazilian National School
}

\section{Feeding Program - a case study}

\section{Opinião de agricultores familiares sobre fornecimento de alimentos orgânicos ao Programa}

\author{
Nacional de Alimentação Escolar - um estudo de caso
}

Opinión de los agricultores familiares sobre el suministro de alimentos orgánicos al Programa Nacional de Alimentación Escolar - un estudio de caso

Received: 09/24/2021 | Reviewed: 09/30/2021 | Accept: 10/03/2021| Published: 10/05/2021

\author{
Angelita Avi Pugliesi \\ ORCID: https://orcid.org/0000-0003-0704-2070 \\ Secretary of Agriculture of Paraná, Brazil \\ E-mail: angepugliesi@gmail.com \\ Anabelle Retondario \\ ORCID: https://orcid.org/0000-0002-8809-5627 \\ Federal University of Paraná, Brazil \\ Email: anabelle@ufpr.br \\ Lize Stangarlin-Fiori \\ ORCID: https://orcid.org/0000-0001-7904-904X \\ Federal University of Paraná, Brazil \\ Email: lizestangarlin@gmail.com \\ Lilian Mitsuko Tanikawa \\ ORCID: https://orcid.org/0000-0001-8338-7295 \\ Federal University of Paraná, Brazil \\ Email: limtanikawa@gmail.com. \\ Maria Eliana Madalozzo Schieferdecker \\ ORCID: https://orcid.org/0000-0002-9400-3717 \\ Federal University of Paraná, Brazil \\ Email: meliana@ufpr.br \\ Suely Teresinha Schmidt \\ ORCID: https://orcid.org/0000-0001-6880-0870 \\ Federal University of Paraná, Brazil \\ Email: suely.ufpr@gmail.com \\ Sila Mary Rodrigues Ferreira \\ ORCID: https://orcid.org/0000-0001-6118-6089 \\ Federal University of Paraná, Brazil \\ Email: sila.ufpr@gmail.com
}

\begin{abstract}
Objective: To investigate the opinion of family farmers about the supply of organic food to the National School Feeding Program (PNAE) in the state of Paraná, Brazil. Method: The convenience sample consisted of 44 family farmers from nine cooperatives and associations located in eight different mesoregions of the state of Paraná that supplied organic food to the PNAE. An online survey was conducted to evaluate the farmers' opinion on possible changes in the cooperatives' revenue and organization; diversification and production increase; difficulties in commercialization; increase in income, and improvement in food consumption after supplying to the PNAE. Results: According to the farmers' opinion, there was better organization (100\%) and an increase in the cooperatives' revenue and production $(86.36 \%$ ), after supplying to the PNAE. $75 \%$ of the farmers diversified their crops and $52.3 \%$ reported an increase of up to $25 \%$ in their family income. In addition, it was reported a better acceptance of the school feeding, diversification in the family's diet, improved self-esteem, closeness between producers and consumers, and the return of family members to the rural property. Conclusion: In the opinion of family farmers, PNAE has been fulfilling its role as a promoter of Food and Nutritional Security in the development of healthy habits, besides contributing to the increase in family income and promoting local sustainable development, following the World Health Organization's agenda.
\end{abstract}

Keywords: School feeding; Organic food; Rural workers; Farmers' associations.

\section{Resumo}

Objetivo: Investigar a opinião de agricultores familiares sobre o fornecimento de alimentos orgânicos ao Programa Nacional de Alimentação Escolar (PNAE) no estado do Paraná. Método: A amostra de conveniência foi constituída 
por 44 agricultores familiares de nove cooperativas e associações, situadas em oito mesorregiões do estado do Paraná, que forneciam alimentos orgânicos ao PNAE. Foi utilizado um questionário eletrônico para avaliar a opinião dos agricultores sobre possíveis alterações no faturamento e organização das cooperativas; diversificação e aumento produtivo; dificuldades na comercialização; incremento na renda e melhoria no consumo alimentar após fornecimento para o PNAE. Resultados: Na opinião dos agricultores, houve melhor organização (100\%), aumento no faturamento e na produção das cooperativas (86,36\%) após fornecimento ao PNAE. 75\% diversificaram as culturas e 52,3\% afirmaram acréscimo de até $25 \%$ na renda familiar. Além disso, relataram melhor aceitação da alimentação escolar, diversificação na alimentação da família, melhora na autoestima, aproximação entre produtores e consumidores e retorno de familiares à propriedade rural. Conclusão: Na opinião dos agricultores familiares, o PNAE vem cumprindo com o papel de promotor da Segurança Alimentar e Nutricional na formação de hábitos saudáveis, além de contribuir para o aumento de renda das famílias e promover o desenvolvimento sustentável local, conforme a agenda da Organização Mundial da Saúde.

Palavras-chave: Alimentação escolar; Alimentos orgânicos; Trabalhadores rurais; Associações de agricultores.

\section{Resumen}

Objetivo: Investigar la opinión de los agricultores familiares sobre el suministro de alimentos orgánicos al Programa Nacional de Alimentación Escolar (PNAE) en el estado de Paraná (Brasil). Método: La muestra de conveniencia estuvo constituida por 44 agricultores familiares de nueve cooperativas y asociaciones, ubicadas en ocho mesorregiones del estado de Paraná/Brasil, que abastecían de alimentos orgánicos al PNAE. Se utilizó un cuestionario electrónico para evaluar la opinión de los agricultores sobre posibles cambios en la facturación y organización de las cooperativas; diversificación y aumento productivo; dificultades en la comercialización; aumento de los ingresos y mejora en el consumo de alimentos después de abastecer al PNAE. Resultados: En opinión de los agricultores, hubo una mejor organización (100\%), aumento en las ganancias y producción de las cooperativas $(86,36 \%)$ luego de abastecer al PNAE. Así, el 75\% diversificó sus cultivos y el 52,3\% afirmó un aumento de hasta un $25 \%$ en los ingresos familiares. Además, reportaron mejor aceptación de la alimentación escolar, diversificación en la dieta familiar, mejora de la autoestima, aproximación entre productores y consumidores y regreso de los miembros de la familia a la propiedad rural. Conclusión: A juicio de los agricultores familiares, el PNAE viene cumpliendo el rol de promover la Seguridad Alimentaria y Nutricional en la formación de hábitos sostenibles, además de contribuir al aumento de los ingresos de las familias y promover el desarrollo local sustentable, según la Agenda de la Organización Mundial de la Salud.

Palabras clave: Alimentación escolar; Alimentos orgânicos; Trabajadores rurales; Asociaciones de agricultores.

\section{Introduction}

Food and Nutrition Security (FNS) is aligned with sustainable development to end world hunger, as per the second Sustainable Development Goal (SDG) on the 2030 agenda of the United Nations (United Nations, 2021). Hence, implementing public policies for rural development aimed at family agriculture (FA) should be a priority, once they stimulate the diversity of crops that constitute the population's staple diet and domestic market supply (Martins, 2021). In addition, FA employs over 10.1 million people in Brazil and represents $23 \%$ of all its agricultural settlements (IBGE, 2017).

In this sense, FA can foster local economies and strategies to fight hunger and poverty in the world, as well as enhance local and regional sustainable development through organic and/or agroecological production (Weber \& Silva, 2021). To do so, it should be strengthened through short supply chain (Conner et al., 2012; López-García et al., 2021; Retiere, 2014; Verano, Figueiredo, \& Medina, 2021; Verano \& Medina, 2021) or farmer networks (Cardoso, Casarotto Filho, \& Catarina, 2021; Verano \& Medina, 2021), to optimize the food flow between producer and consumer. Such initiative can increase jobs and local income, in addition to helping create ties that might retain farmers in rural areas (Retiere, 2014). However, it requires the articulation of public policies.

Since the 2000s, public policies targeting FA have been instituted and/or restructured in Brazil. The National School Feeding Program (PNAE) is the oldest FNS public policy in the country. Since its creation in 1955, it has been improved to promote FNS and, more recently, to foster agroecology (Sousa, Silva, Azevedo, \& Ramos, 2015; Toyoyoshi, Oliveira, Santos, Galisa, \& Galante, 2013). The purpose of PNAE is to promote a satisfactory nutritional condition for its beneficiaries contributing to learning, school performance, and the development of healthy eating habits — as well as stimulate sustainable development, local economy, and FA (Brasil, 2009a; da Cunha, de Sousa, \& Machado, 2010). 
The PNAE legislation establishes that at least 30\% (Brasil, 2009a) of the financial resources transferred by the Federal Government to the municipalities must be invested in the direct purchase of food produced by family farmers (A. M. Peixinho, 2013), preferably organic food (Brasil, 2009a, 2009b, 2013; A. M. Peixinho, 2013). Thus, small and medium-sized rural producers receive support for local food production (Lopes \& Doula, 2019; Souza-Esquerdo \& Bergamasco, 2014), which promotes sustainability and connects rural and urban areas (Triches \& Schneider, 2010). Moreover, through the partnership with family farmers, PNAE is able to contribute to FNS (A. M. Peixinho, 2013), promoting a higher consumption of fresh fruits and vegetables by students and contributing to a better quality of life and the prevention of obesity and non-transmissible chronic diseases (Brasil, 2009a; da Cunha et al., 2010).

Furthermore, the purchase of food from FA by the municipalities fosters the sustainability of the agrifood systems and local food sovereignty (da Cunha et al., 2010; A. Peixinho, Balaban, Rimkus, Schwartzman, \& Galante, 2011; Saraiva et al., 2013; Silva \& Sousa, 2013; Toyoyoshi et al., 2013; Triches \& Schneider, 2010). However, even with the many benefits of the implementation of the PNAE guidelines in Brazilian states and municipalities, the process of purchasing from FA is still difficult to administrate and needs to be improved.

In 2010, the state of Paraná was the first to meet the legal goals for the purchase of food from FA (Brasil, 2009a) and has been sustaining the purchases of organic and/or agroecological food from this group of farmers over the years. However, the impact of this practice on the cooperatives and farmers' family's life has not been researched so far. Thus, this study aims to investigate the opinion of family farmers from the state of Paraná on changes associated with production, commercialization, income, and food consumption after the supply of organic food to the PNAE started.

\section{Methodology}

A cross-sectional and descriptive study was conducted to evaluate the opinion of family farmers who supplied organic food to the School Feeding Program of the state of Paraná through PNAE in the 2014-2015 biennium. The project was approved by the Ethics Committee for Human Research of the Federal University of Paraná's Health Sciences Sector (CAAE number 0058.0.091.000-08) and authorized by the Secretary of Education of the state of Paraná.

The research population consisted of all the cooperatives and associations that supplied organic food to the PNAE during the referred period $(n=20)$. The cooperatives and associations that supplied only one type of food, only fresh herbs, or only food obtained from extractivism (e.g., pine nuts, Brazilian grape) were excluded from the study ( $\mathrm{n}=10$ ), as well as one cooperative that ceased its activities in 2014. Thus, nine cooperatives and associations participated in the research, totaling 1600 cooperative members. These cooperatives and associations were located in eight mesoregions of the state of Paraná, namely: Northwest, Central North, North Pioneer, West, Central Western, Southwest, Southeast, and the Metropolitan Area of Curitiba. The convenience sample consisted of 44 family farmers who agreed to participate in the study by signing the Informed Consent Form (ICF) and filling out the data collection instrument.

The survey was adapted from the School Food and Nutrition Department (Stolarski, 2014) of the state of Paraná and consisted of 41 questions. There were investigated characteristics of the cooperatives and the respondents; changes in revenue, organization, and participation in the cooperatives; diversification and increase in production; difficulties in commercialization; increase in income; and improved food consumption by the families after being hired to supply school feeding. To analyze diversification and increase in production, the products cultivated by the family farmers were categorized into pre-specified groups (Secretaria de Estado da Educação do Paraná (SEED/PR), 2014).

Before the research was initiated, we contacted the presidents of the cooperatives and associations, explaining our objectives and requesting the participation of the cooperative family farmers who produced organic food. At the beginning of the data collection, we sent the cooperatives a standard email containing the ICF and a cover letter. The survey was sent via 
Google Drive. The documents were also available at the cooperatives' offices or sent by email for the farmers to check and fill out. The answers were collected between December 2014 and January 2015.

Later, the answers were transferred to an Excel (2010) spreadsheet and a descriptive statistical analysis was performed using the Statistical Package for the Social Sciences (SPSS) software, version 20.0. In addition, a Pearson chi-square test was performed to verify the association between the farmers' opinions on the improvements in the cooperatives and on the changes observed in their family units $(\mathrm{p}<0.05)$.

\section{Results}

Of the 44 farmers participating in the study, $79.5 \%$ were male and a significant number had finished elementary school $(47.7 \%)$, while $25 \%$ had graduated from college. As for the cooperatives and associations, the majority produced only organic food (72.7\%) that was sold to the municipal PNAE (75.0\%) and had an increase in production after supplying to the program $(95.5 \%)$. Commercialization to the PNAE also had a positive impact on sales and crop diversification: $57.6 \%$ of the producers diversified from 1 to 10 types of crops, while $30.3 \%$ diversified from 11 to 20 (Table 1).

Table 1 - Family farmers, cooperatives, and associations that supply organic food to the PNAE in the state of Paraná and crop diversification. Paraná, Brazil, 2014-2015 biennium.

\begin{tabular}{|c|c|c|}
\hline Data & $\mathrm{n}$ & $\%$ \\
\hline \multicolumn{3}{|l|}{ Sex } \\
\hline Female & 09 & 20.5 \\
\hline Male & 35 & 79.5 \\
\hline \multicolumn{3}{|l|}{ Educational level } \\
\hline Elementary School & 21 & 47.7 \\
\hline High School & 12 & 27.3 \\
\hline College/University & 11 & 25.0 \\
\hline Participation in cooperatives' administrative positions & 24 & 54.5 \\
\hline \multicolumn{3}{|l|}{ Type of cooperative production } \\
\hline Organic & 32 & 72.7 \\
\hline Conventional and organic & 12 & 23.3 \\
\hline Commercialization for the municipal PNAE & 33 & 75.0 \\
\hline Increased production after selling to the PNAE & 42 & 95.5 \\
\hline Production diversification after supplying to the PNAE & 33 & 75.0 \\
\hline From 1 to 10 types of organic crops & 19 & 57.6 \\
\hline From 11 to 20 types of organic crops & 10 & 30.3 \\
\hline From 21 to 32 types of organic crops & 04 & 12.1 \\
\hline Crop diversification & $\begin{array}{c}\text { number of } \\
\text { crops* }\end{array}$ & $\begin{array}{c}\% \text { of total } \\
\text { crops }\end{array}$ \\
\hline Vegetables and tubers & 133 & 39.0 \\
\hline Vegetables and fresh herbs & 92 & 27.0 \\
\hline Fruit & 84 & 24.6 \\
\hline Complements & 10 & 2.8 \\
\hline Bakery products & 7 & 2.1 \\
\hline Yogurt and similar & 5 & 1.5 \\
\hline Cereals & 3 & 0.9 \\
\hline Beans & 2 & 0.6 \\
\hline Juices & 2 & 0.6 \\
\hline Meat and eggs & 2 & 0.6 \\
\hline Milk & 1 & 0.3 \\
\hline Total & 341 & 100.0 \\
\hline
\end{tabular}

Note: *The participant could choose more than one option; Source: Authors. 
The reasons highlighted by the producers for transitioning from conventional to organic farming were: their family's and their own health $(97.7 \%)$, better remuneration $(88.6 \%)$, consumer's health $(84.1 \%)$, and the environment $(75.0 \%)$. The difficulties reported were: labor demand (77.3\%), lack of technical assistance (50.0\%), certification process $(43.2 \%)$, and acquisition of creole seeds (40.9\%). However, $86.6 \%$ of the farmers believe that the benefits of PNAE have stimulated organic farming and $65.9 \%$ knew other producers who have made the transition or would like to make it in order to sell to the program (Table 2).

Table 2 - Motivations for organic food production and difficulties of family farmers in the production and commercialization of these foods in the state of Paraná, Brazil, 2014-2015 biennium ( $\mathrm{n}=44)$.

\begin{tabular}{|c|c|c|}
\hline Data & $\mathrm{n}$ & $(\%)$ \\
\hline \multicolumn{3}{|l|}{ Reasons for organic production* } \\
\hline Health of the farmers and their families & 43 & 97.7 \\
\hline Better remuneration & 39 & 88.6 \\
\hline Consumer's health & 37 & 84.1 \\
\hline Environment & 33 & 75.0 \\
\hline Closeness to the organic cooperative & 1 & 2.3 \\
\hline \multicolumn{3}{|l|}{ Difficulties in organic production* } \\
\hline High labor demand & 34 & 77.3 \\
\hline Absence of organic-specific RTA & 22 & 50.0 \\
\hline Organic certification process & 19 & 43.2 \\
\hline Creole seeds acquisition & 18 & 40.9 \\
\hline Lower productivity & 14 & 31.8 \\
\hline Fear of losing production & 12 & 27.3 \\
\hline Low product acceptance due to appearance & 5 & 11.4 \\
\hline Absence of trade channels or incentives for ecological transition & 1 & 2.3 \\
\hline Neighbors use pesticides & 1 & 2.3 \\
\hline \multicolumn{3}{|l|}{ Incentives to organic farming provided by the PNAE } \\
\hline The legal benefits of the PNAE stimulate organic farming & 39 & 86.6 \\
\hline Other farmers made the ecological transition to the PNAE & 29 & 65.9 \\
\hline Other farmers would like to make the transition in order to sell to the PNAE & 34 & 77.3 \\
\hline Sale guarantee, safe commercialization channel & 16 & 41.0 \\
\hline Higher price, income, value & 10 & 25.6 \\
\hline Food good for health and soil, and with better quality. & 6 & 13.6 \\
\hline Priority required planning and organization & 5 & 11.4 \\
\hline Promotion, advertising and acceptance of the organic product & 3 & 6.8 \\
\hline Interested farmers and more cooperatives and associations' members & 3 & 6.8 \\
\hline \multicolumn{3}{|l|}{ Difficulties in commercialization* } \\
\hline Low prices for some products & 40 & 90.9 \\
\hline Small quantities traded & 19 & 43.2 \\
\hline Low acceptance of organic food by school cooks & 17 & 38.6 \\
\hline Logistics of the point-to-point delivery & 15 & 34.1 \\
\hline Schools' lack of receptivity & 8 & 18.2 \\
\hline Schools' lack of knowledge about deliveries & 8 & 18.2 \\
\hline Lack of scales for product checking during delivery & 8 & 18.2 \\
\hline Delay in payments by the Executing Agency & 7 & 15.9 \\
\hline Insufficient production to meet the requested demand & 7 & 15.9 \\
\hline Brazilian Health Regulatory Agency requirements & 6 & 13.6 \\
\hline Relationship problems with the Executing Agency & 0 & 0.0 \\
\hline \multicolumn{3}{|l|}{ Acceptance of vegetables in school meals* } \\
\hline Children and adolescents do not have the habit of consuming fruit & 17 & 38.6 \\
\hline The amount of vegetables would be insufficient for everyone & 13 & 29.5 \\
\hline Children and adolescents do not like vegetables & 12 & 27.3 \\
\hline The school cooks do not prepare the food, they let it spoil & 10 & 22.7 \\
\hline Teachers do not stimulate the consumption of vegetables & 5 & 11.4 \\
\hline \multicolumn{3}{|l|}{ Changes in school feeding after the program* } \\
\hline More varied and colorful meals & 40 & 90.9 \\
\hline Students are discovering different foods & 34 & 77.3 \\
\hline Students are getting access to food they can not afford & 28 & 63.6 \\
\hline Students value fresh and healthy food & 18 & 40.9 \\
\hline
\end{tabular}

Note: RTA, Rural Technical Assistance; PNAE, National School Feeding Program. Multiple choice questions. Source: Authors. 
Some of the farmers think that selling to the PNAE represents a safe commercialization channel (41.0\%) and offers a better selling price $(25.6 \%)$. On the other hand, they also believe that the low prices of some products (90.9\%) and the small quantities sold (43.2\%) represent difficulties in commercialization, as well as the low acceptance of organic food by school cooks $(38.6 \%)$ and the logistics of point-to-point delivery $(34.1 \%)$. None of the producers reported having stopped selling their products due to relationship problems with the Executing Agency, represented by the State Secretary of Education/Institute for Educational Development of Paraná (Fundepar).

As for the main difficulties regarding the acceptance of vegetables in school feeding, family farmers believe that children do not have the habit of eating fruit $(38.6 \%)$; that the amount of vegetables would be insufficient for everyone (29.5\%); and that children and teenagers do not like vegetables $(27.2 \%)$. In addition, $22.7 \%$ of the producers think that the school cooks do not prepare the food, which ends up spoiled. On the other hand, family farmers believe that organic food makes meals more varied and colorful (90.9\%), that it allows students to discover new types of food (77.3\%), and that school meals from family farming allow students to have access to food that they could not afford otherwise (63.6\%).

Food consumption in the family units of $75 \%$ of the farmers has greatly improved due to diversification of planting, greater variety or barter $(61.4 \%)$, and consumption of healthy foods $(31.8 \%)$. Furthermore, all participants affirmed that their family income increased after they started supplying to the PNAE (11.4\% reported an over 50\% increase), which brought an improvement in self-esteem (100\%), the return of family members to the farm $(81.8 \%)$, greater digital inclusion $(79.5 \%)$, closer contact with the consumers (75.0\%), and hiring of temporary employees (43.2\%) (Table 3).

Table 3 - Changes in family units of organic food farmers after supplying to PNAE, Paraná, Brazil, 2014-2015 (n=44).

\begin{tabular}{lcc}
\hline Data & $\mathrm{n}$ & $\%$ \\
\hline Food consumption after adherence to the program & 0 & 0.0 \\
It was harmed & 1 & 2.3 \\
No changes & 10 & 22.7 \\
Slightly improved & 33 & 75.0 \\
Greatly improved & 27 & 61.4 \\
Improved food consumption & 14 & 31.8 \\
Crop diversification, increased variety, barter & 8 & 18.2 \\
Healthy, natural, and pesticide-free food & 6 & 13.6 \\
More quantity, leftovers, more access & 2 & 4.6 \\
Higher family income, better price & & 52.3 \\
Greater planning, organization and union & 23 & 36.4 \\
Increase in family income after adherence to the program & 16 \\
Up to 25\% & 4 & 9.1 \\
From 26\% to 50\% & 1 & 2.3 \\
From 51\% to 75\% & & 100.0 \\
From 76\% to 100\% & 44 \\
Changes in family units after PNAE* & 44 \\
Increase in family income & 100.0 \\
Improved self-esteem & 36 \\
Return of family members to the farm & 35 & 81.8 \\
Greater digital inclusion & 33 \\
Closer proximity to consumers & 19 & 75.5 \\
Family hired temporary employees & 43.2 \\
\hline
\end{tabular}

Note: *multiple choice question. Source: Authors.

Closeness between farmers and consumers was associated with the improved self-esteem of farmers $(\mathrm{p}=0.005)$. The fact that the cooperative's production is $100 \%$ organic, in turn, was associated with better food consumption by the producers' families $(\mathrm{p}<0.001)$ (data not shown). 
Regarding the cooperatives, supplying to the PNAE also resulted in increased revenue (86.3\%), better organization (100\%), more women participation (100\%), incentive for cooperativism (97.7\%), hiring of employees (95.5\%), and more young people participation $(81.8 \%)$. Additionally, the increased revenue made it possible to invest in the cooperatives, which reflected on the family units (Table 4).

Table 4 - Opinion of family farmers regarding improvements in cooperatives and associations of the Paraná state after supplying to PNAE. Paraná state, Brazil, 2014-2015 biennium ( $\mathrm{n}=44)$.

\begin{tabular}{lcc}
\hline Data & $\mathrm{n}$ & $\%$ \\
\hline Increase in production and revenue & 8 & 18.2 \\
$<25 \%$ & 21 & 47.7 \\
$>25 \%$ to $<50 \%$ & 2 & 4.5 \\
$>50 \%$ to $<75 \%$ & 3 & 6.8 \\
$75 \%$ to $100 \%$ & 4 & 9.1 \\
More than the double & 6 & 13.7 \\
Farmer did not have this data & \\
Changes* & 44 & 100.0 \\
Better organization & 44 & 100.0 \\
Increased women participation & 43 & 97.7 \\
Encouragement of cooperativism & 42 & 95.5 \\
Hiring of employees & 36 & 81.8 \\
Young people increased participation & & \\
Investments & 28 & 63.6 \\
Acquisition of refrigeration equipment & 22 & 50.0 \\
Construction of kitchen or family agricultural business & 18 & 40.9 \\
Acquisition of vehicle & 15 & 34.1 \\
Acquisition of food preparation equipment & 14 & 31.8 \\
Repairs and renovations & 14 & 31.8 \\
Acquisition of computers & 11 & 25.0 \\
Storage shed construction & &
\end{tabular}

Note: *Multiple choice question. Source: Authors.

\section{Discussion}

In the opinion of the farmers who participated in our research, PNAE has been fulfilling its role as a promoter of FNS by fostering food diversification, employment, income generation for farming families, cooperatives and associations, and by contributing to local sustainable development.

The fact that most of the organic farmers were men is aligned with gender issues in rural areas. Social reproduction in this environment excludes women, both in income-generating work and the succession of family property. In addition, it is difficult for them to conciliate an extensive rural work routine with their domestic and school activities, given that the schooling level of rural women is higher than that of men (Martins, 2021).

The role played by women in conventional FA is less empowering (López-García et al., 2021). A possible way to empower them in organic FA includes feminist support for institutionalizing programs that make the gender dynamic more equal (Waltz, 2016). In this sense, all the research participants mentioned that the greater participation of women was one of the positive changes in the cooperatives and associations.

The difficulty of including cooperatives' proposals in public calls through digital processes (Lopes \& Doula, 2019) may be a limitation for family farmers who reported having only primary education, as it requires people with more experience and constant monitoring, which is usually not possible in small municipalities (Lopes \& Doula, 2019). According to the Brazilian Institute of Geography and Statistics (IBGE, 2017), approximately 90\% of municipalities in the state of Paraná have less than 20,000 inhabitants, and 50\% have less than 10,000 . 
Most farmers (54.5\%) reported working both in organic food production and unpaid administrative positions of the cooperatives, such as president, vice-president, and treasurer. In cases where the farmer was required to stay at the office, an employment relationship was created, which shows that PNAE offers a mechanism for social control through the participation of members of the school community and civil society in management control (A. Peixinho et al., 2011).

Even if the State provides policies that support food acquisition from FA for school feeding, there are still difficulties in effectively making this purchase (Lopes \& Doula, 2019). Only 40\% of the organic production is sold to school feeding programs, as the rest is supplied to local open markets and supermarkets. In addition, despite $86 \%$ of Brazilian municipalities purchasing food from FA for the PNAE, the national average purchase is only 22\% (Bocchi, Magalhaes, Rahal, Gentil, \& Goncalves, 2019). Therefore, a local social articulation is necessary to foster other means of production outflow, as well as the creation of new market perspectives for FA (Cardoso et al., 2021; Triches \& Schneider, 2010).

For PNAE to fulfill its role in promoting the Human Right to Adequate Food (HRAF), it is essential to support FA, due to its potential to generate employment and income, lower food transportation costs, and promote the recognition of local production, creating a connection between the countryside and the urban environment (Saraiva et al., 2013; Weber \& Silva, 2021). These changes show that public policies such as PNAE can enhance the local development process since their purchases move billions of reais annually, heating up the local economy and contributing to the regional socio-economic development (Lopes \& Doula, 2019).

Crop diversification suggests a positive impact on economic development and quality of life (Bassan, 2014; Campi, Dueñas, \& Fagiolo, 2021; Lopes \& Doula, 2019), highlighting the region's productive potential (Vitte, 2006) and the role of social actors in stimulating and enabling local economic changes (Campi et al., 2021; Lopes \& Doula, 2019). The choice for vegetable, tuber, and fruit crops impact people's quality of life, since it contributes to a healthy diet and suggests that the State is adopting the PNAE guidelines by using diversified foods that respect the culture and traditions of the region (dos Santos, Fernandes, Rockett, \& de Oliveira, 2014; Toyoyoshi et al., 2013). Furthermore, it aligns with the Dietary Guidelines for the Brazilian Population (Brasil, 2014), which advocates for a varied diet based on fresh or minimally processed food. Thus, diversifying agricultural production increases the options for school meals while reducing the food deficit risk and contributing to food systems' sustainability (Campi et al., 2021).

Even though most of the cooperatives and associations surveyed in this study produced exclusively organic food, part of them $(23.3 \%)$ still used pesticides in part of their production or were transitioning to organic farming. Reasons for this transition, such as economic growth and consumers' health, have also been mentioned in other studies (dos Santos et al., 2014). It suggests that family farmers know the organic farming practice, its positive influence on family income, and the importance of consuming pesticide-free food, as the presence of chemical inputs in food endangers the consumer (dos Santos et al., 2014) and leads to acute effects and diseases such as cancer, congenital malformations, and endocrine, neurological and mental disorders (WHO, 2002). Thus, providing healthy food allows schools to promote health, nutritional and environmental education. Moreover, PNAE participation in the transition to organic farming shows that this policy has been fulfilling a role in promoting FNS, agroecology, and sustainable development (Sousa et al., 2015; Toyoyoshi et al., 2013).

To farmers, cooperatives, and associations, limitations in the food commercialization to schools may result from difficulties in transportation, seasonality of production, and lack of subsidies, incentives, agricultural research and technical assistance (Lima \& Sousa, 2011; Silva \& Sousa, 2013), reinforcing the need for cross-sector actions of knowledge exchange with farmers. For example, technical support to FA can help to diversify the production and include regional products in school meals (Monego et al., 2013) since skilled labor is essential for the production and acquisition of quality organic food (Lopes \& Doula, 2019). Likewise, family farmers need the assistance of nutritionists (Pires et al., 2017), cooperatives, or government agencies to solve problems and understand the food acquisition process. Participating in open calls, despite being easier than 
participating in public procurements, can still be complex and bureaucratic for people who have no practice with such processes, as may be the case for some family farmers (Becker, Andersson, Altemburg, \& Costa, 2011; Pires et al., 2017; Triches \& Schneider, 2010).

In this sense, it is up to the technical assistance entities, cooperatives, and associations to help producers plan their production and meet the demands of school feeding programs. Moreover, the State has a major role both in relation to public procurement mechanisms and the promotion of food chains, resources, and regulations that foster sustainable practices and healthy eating habits (Brasil, 2009a).

Organic food acceptance requires the exchange of knowledge and experiences of those involved in the production process, managers, nutritionists, school cooks (Sousa et al., 2015), teachers, and students. Furthermore, supporting and recognizing the work of school cooks can increase their commitment since, by preparing the menu, these professionals promote the health of students (Lima \& Sousa, 2011), which also involves an affective relationship with them. Nevertheless, recognizing their role as educational and health agents depends on structural changes, values, conceptions, and insertions in the school environment (Fernandes, Fonseca, \& Silva, 2014).

In addition, for school feeding programs to succeed, school cooks must understand the commercialization process of the food produced in the region (Bontrager Yoder et al., 2014) since its appearance may differ from the conventional one and, consequently, the product can be rejected despite its benefits regarding health, taste, and durability.

The menu offered to students should consider local eating habits, food and nutritional composition, balance, flavor, and sustainability (Silverio \& Sousa, 2014). To achieve these goals, it is necessary to articulate managers, nutritionists, farmers, and cooperatives (Pires et al., 2017; Silva \& Sousa, 2013), as well as provide training, technical and government support, educational strategies, community awareness, supply organization that considers the demand for organic food, and improvement of the food production management (Silverio \& Sousa, 2014). However, the reduced number of nutritionists (Lima \& Sousa, 2011; Pires et al., 2017) assisting the municipalities, as well as the high turnover of school cooks, who are mostly temporary employees, and the many duties they perform, can make it difficult to meet these objectives in the short term.

According to the farmers' opinions, among the difficulties for the acceptance of organic food in school meals are the fact that children and adolescents do not have the habit of eating fruits and do not like vegetables, aside from the insufficient amount of food available. This may be related to deficiencies in schools' physical structure, issues with the logistics of food receiving/storage (Sousa et al., 2015), and absence of government actions that align with the actors involved both in the training of school cooks and food and nutrition educational actions. It is necessary to address socioeconomic and environmental aspects of agrifood systems, appreciation for local cuisine, and the role of schools as promoters of health and healthy eating (Porto, Schmitz, Recine, \& Rodrigues, 2015).

Despite these obstacles, PNAE promoted successful changes in school meals that increased diversification and stimulated both vegetable consumption and students' access to these foods, which was also identified by Silva \& Sousa (Silva \& Sousa, 2013). On the other hand, the labor demand was one of the difficulties reported in organic food production (Silva \& Sousa, 2013).

Organic crop inclusion and menu diversification, which ensures healthy and safe feeding, may be the cause of the improved food consumption shown by farmers' families after supplying to the PNAE and consequently increasing their income. Thus, in addition to aiming for a FNS to the population, public policies for food acquisition from FA also aim to increase farmers' income (Salgado \& Dias, 2013). Furthermore, the use of regional foods promotes sustainability (LópezGarcía et al., 2021), healthy eating practices, and respect for the communities' cultural and food identity (Monego et al., 2013). 
Closeness between producers and consumers was associated with farmers' increased self-esteem (data not shown). This increase earned through recognition of farmers' social and ecological role makes agroecology a practice that promotes FNS and health (Navolar, Rigon, \& Philippi, 2010). The personal relationships that permeate trading with both commercial and symbolic exchanges create a trust relationship between producers and consumers (Triches \& Schneider, 2010). Furthermore, the proximity between farmers and society favors the exchange of ideas and local solutions, contributing to the maintenance and development of the region (López-García et al., 2021; Turpin, 2015). Besides the positive impact on self-esteem, these changes in family units have promoted the return of family members to rural property (urban exodus), greater digital inclusion, closer ties between producers and institutional consumers (school cooks, teachers, students), and the hiring of temporary employees by family members. Thus, PNAE strengthens organic FA and stimulates the migration of farmers to rural areas (Silva \& Sousa, 2013).

PNAE's food purchase from family farmers is a short food supply chain strategy that promotes proximity between farmers and consumers through trust, loyalty, and information exchange (Dias, Révillion, \& Talamini, 2017; López-García et al., 2021; Verano et al., 2021). Moreover, this policy addresses economic aspects that avoid elitist market niches and large groups of the agrifood system and include fair trade, local economy insertion, capacity for continuous modernization of production tools, food safety, production for self-consumption, and social economy through cooperatives and civil society organizations (Weber \& Silva, 2021).

The exclusive production of organic food was associated with improved food consumption of the farmers' families. According to Deaconu et al. (Deaconu, Berti, Cole, Mercille, \& Batal, 2021), organic food farmers have healthier eating habits since their greater dietary diversity promotes adequate nutrient intake through the increased consumption of fresh or minimally processed foods and reduction of ultra-processed foods.

Cooperatives' increased production and revenue after supplying to the PNAE was reported by $86.3 \%$ of the farmers, similar to the $86.5 \%$ production increase reported by Silva \& Sousa (Silva \& Sousa, 2013). These findings suggest farmers' adherence to the program, which may result from strategies such as the organization of managers and farmers, support from representative entities, and cooperation among producers. Likewise, municipal councils also play an important role in this process since they contribute to the convergence of public and private sectors in the regulations' enforcement and meeting of school demands (Bezerra et al., 2013; Turpin, 2009).

The impact of organic food commercialization on cooperatives and associations reinforces that the food supply to the PNAE favors the organization of family farmers, strengthens cooperatives, contributes to direct employment, and, consequently, increases FA organic food production (Turpin, 2009).

Investments show a concern with improving the physical structure of production units, which can lead to cooperatives' autonomy in production and commercialization and the adequacy of sanitary regulations that meet identity and quality standards, as this is the main difficulty for purchasing FA products (Triches \& Schneider, 2010). This confirms that the participation of the agricultural supply chain contributes to positive social and economic results (Rutherford, Burke, Cheung, \& Field, 2016).

Moreover, the results suggest that supporting family farmers who produce organic food promotes employment and income generation, as well as the diversity of healthy and quality food (Triches \& Schneider, 2010). This preserves regional habits and connects the countryside to the city, contributing to FNS as a right to adequate food.

Among the limitations of our study, we highlight the low rate of replies to our survey, which impacted the sample size and may be related to the family farmers' difficulty in completing electronic surveys. However, the choice for digital tools was made in order to increase the research scope. Thus, as strengths, we highlight the coverage of eight out of the ten mesoregions 
of the state of Paraná. Furthermore, we presented the point of view of the family farmers themselves towards their practices and the public policies that aim at improving them.

\section{Conclusion}

The organic food supply to the PNAE has promoted positive changes in food diversification, commercialization, family income, self-esteem, return of family members to the farm, and digital inclusion among farmers. Likewise, there has been an increase in cooperatives' diversity of production and revenues, direct employment, participation of young people and women, internal organization, and investments.

Thus, from the perspective of family farmers who produce organic food, PNAE has been fulfilling its role as a FNS promoter by contributing to the development of healthy habits, family income, and local sustainability, following the WHO agenda.

It is important that public policies continue to stimulating organic food employment in the Program implementation to promote FNS to family farmers and childcare. Future studies could investigate this issue from the perspective of the PNAE's beneficiaries. Complementary studies could bring to light the PNAE's execution during the Covid-19 pandemic.

\section{Acknowledgments}

The authors would like to thank the cooperatives, associations and family farmers in the state of Paraná that were part of the study, and the Academic Publishing Advisory Center (CAPA) of the Federal University of Paraná.

\section{References}

Bassan, D. (2014). Alguns aspectos teóricos do desenvolvimento com o olhar na região do Vale do Paranhana. RDE - Revista de Desenvolvimento Econômico, 1, 39. 10.21452/rde.v16i29.2949

Becker, C., Andersson, F. d. S., Altemburg, S. G. N., \& Costa, L. C. (2011). 10766 - Novas concertações sociais e antigos entraves “burocráticos”: a produção de base familiar e ecológica frente aos desafios de acesso ao PNAE. Cadernos de Agroecologia; v. 6 n. 2 (2011): VII Congresso Brasileiro de Agroecologia Fortaleza - 2011.

Bezerra, O. M. d. P. A., Bonomo, É., Silva, C. A. M. d., Correa, M. d. S., Souza, A. A. d., Santos, P. C. T. d., \& Souza, D. M. S. d. (2013). Promoção da aquisição de produtos da agricultura familiar para a alimentação escolar em Territórios da Cidadania de Minas Gerais e Espírito Santo. Revista de Nutrição, 26(3), 335-342. 10.1590/S1415-52732013000300008

Bocchi, C. P., Magalhaes, E. S., Rahal, L., Gentil, P., \& Goncalves, R. S. (2019). The nutrition decade, the public policy for food security, and public purchases from family farming in BrazilEl Decenio de las Naciones Unidas de Accion sobre la Nutricion, la politica de seguridad alimentaria y nutricional, y las compras publicas de la agricultura familiar en Brasil. Rev Panam Salud Publica, 43, e84. 10.26633/RPSP.2019.84

Bontrager Yoder, A. B., Liebhart, J. L., McCarty, D. J., Meinen, A., Schoeller, D., Vargas, C., \& LaRowe, T. (2014). Farm to elementary school programming increases access to fruits and vegetables and increases their consumption among those with low intake. J Nutr Educ Behav, 46(5), 341-349. 10.1016/j.jneb.2014.04.297

Brasil. Lei $\mathrm{n}^{\circ} 11.947$, de 16 de junho de 2009. Dispõe sobre o atendimento da alimentação escolar e do programa dinheiro direto na escola aos alunos da educação básica (2009a). Brasília: FNDE.

Brasil. Resolução/CD/FNDE n 38, de 16 de julho de 2009. Dispõe sobre o atendimento da alimentação escolar aos alunos da educação básica no Programa Nacional de Alimentação Escolar - PNAE. (2009b). Brasília: FNDE.

Brasil. Resolução/CD/FNDE nº 26, de 17 de junho de 2013. Dispõe sobre o atendimento da alimentação escolar aos alunos da educação básica no âmbito do Programa Nacional de Alimentação Escolar - PNAE. (2013). Brasília: FNDE.

Brasil. (2014). Guia Alimentar para a População Brasileira. https://goo.gl/pjD97r

Campi, M., Dueñas, M., \& Fagiolo, G. (2021). Specialization in food production affects global food security and food systems sustainability. World Development, 141, 105411. https://doi.org/10.1016/j.worlddev.2021.105411

Cardoso, J. d. F., Casarotto Filho, N., \& Catarina, A. S. (2021). Small business networks as a strategy for the development of organic agriculture. Revista Brasileira de Gestão e Desenvolvimento Regional, 17(1), 35-47.

Conner, D., King, B., Kolodinsky, J., Roche, E., Koliba, C., \& Trubek, A. (2012). You can know your school and feed it too: Vermont farmers' motivations and distribution practices in direct sales to school food services. Agriculture and Human Values, 29(3), 321-332. 10.1007/s10460-012-9357-y 
da Cunha, E., de Sousa, A. A., \& Machado, N. M. (2010). Organic food and educational actions in schools: diagnosis for health and nutrition education. Cien Saude Colet, 15(1), 39-49. 10.1590/s1413-81232010000100009

Deaconu, A., Berti, P. R., Cole, D. C., Mercille, G., \& Batal, M. (2021). Agroecology and nutritional health: A comparison of agroecological farmers and their neighbors in the Ecuadorian highlands. Food Policy, 101, 102034. https://doi.org/10.1016/j.foodpol.2021.102034

Dias, V. V., Révillion, J. P., \& Talamini, E. (2017). Cadeias curtas de alimentos orgânicos: aspectos das relações de proximidade entre consumidores e agricultores no Brasil. In M. G. S. S. (Orgs.) (Ed.), Cadeias curtas e redes agroalimentares alternativas: negócios e mercados da agricultura familiar. Porto Alegre: UFRGS.

dos Santos, F., Fernandes, P. F., Rockett, F. C., \& de Oliveira, A. B. (2014). Evaluation of the inclusion of organic food from family-based agriculture in school food in municipalities of rural territories of the state of Rio Grande do Sul, Brazil. Cien Saude Colet, 19(5), 1429-1436. 10.1590/141381232014195.14982013

Fernandes, A. G. d. S., Fonseca, A. B. C. d., \& Silva, A. A. d. (2014). Alimentação escolar como espaço para educação em saúde. Cien Saude Colet, 19(1), 3948. $10.1590 / 1413-81232014191.1711$

IBGE. (2017). Censo Agropecuário, Florestal e Aquícola 2017. Agricultura familiar e não familiar. IBGE https://censos.ibge.gov.br/agro/2017/2012-agenciade-noticias/noticias/25786-em-11-anos-agricultura-familiar-perde-9-5-dos-estabelecimentos-e-2-2-milhoes-de-postos-de-trabalho.html.

Lima, E. E. d., \& Sousa, A. A. d. (2011). Alimentos orgânicos na produção de refeições escolares: limites e possibilidades em uma escola pública em Florianópolis. Revista de Nutrição, 24(2), 263-273. 10.1590/S1415-52732011000200007

Lopes, B. d. J., \& Doula, S. M. (2019). Deficiências no Processo de Compras Governamentais do Programa Nacional de Alimentação Escolar e seus Impactos no Desenvolvimento Local. Desenvolvimento em Questão, 17(48), 175-192. 10.21527/2237-6453.2019.48.175-192

López-García, D., Cuéllar-Padilla, M., de Azevedo Olival, A., Laranjeira, N. P., Méndez, V. E., Peredo y Parada, S., \& Tendero-Acín, G. (2021). Building agroecology with people. Challenges of participatory methods to deepen on the agroecological transition in different contexts. Journal of Rural Studies, 83 , 257-267. https://doi.org/10.1016/j.jrurstud.2021.02.003

Martins, L. R. (2021). Juventude rural no Brasil: referências para debate. Estudos Sociedade e Agricultura, 29(1), 94-112. 10.36920/esa-v29n1-7

Monego, E. T., Alexandre, V. P., Sousa, L. M. d., Martins, K. A., Rosa, J. Q. S., Souza, P. L. C. d., \& Assis, J. N. d. (2013). Produção e potencial agrícolas de alimentos destinados à alimentação escolar em Goiás e no Distrito Federal, na Região Centro-Oeste do Brasil. Revista de Nutrição, 26(2), 233-241. $10.1590 / \mathrm{S} 1415-52732013000200011$

Navolar, T. S., Rigon, S. d. A., \& Philippi, J. M. d. S. (2010). Dialogues between agroecology and health promotion. RBPS, 23(1), 69-79.

Peixinho, A., Balaban, D., Rimkus, L., Schwartzman, F., \& Galante, A. P. (2011). Alimentação Escolar no Brasil e nos Estados Unidos. O Mundo da Saúde, $35(2), 128-136$

Peixinho, A. M. (2013). The trajectory of the Brazilian School Nutrition Program between 2003 and 2010: report of the national manager. Cien Saude Colet, 18(4), 909-916. 10.1590/s1413-81232013000400002

Pires, P. F. F., Retondario, A., Almeida, C. C. B., Schmidt, S. T., Beux, M. R., \& Ferreira, S. M. R. (2017). Professional practice of dietitians in the Brazilian School Feeding Program: A multiple case study. Revista de Nutrição, 30(4), 499-510. 10.1590/1678-98652017000400009

Porto, E. B. S., Schmitz, B. A. S., Recine, E., \& Rodrigues, M. d. L. C. F. (2015). School canteens in the Federal District, Brazil and the promotion of healthy eating. Revista de Nutrição, 28(1), 29-41. 10.1590/1415-52732015000100003

Retiere, M. I. H. (2014). Agricultores inseridos em circuitos curtos de comercialização: modalidades de venda e adaptações dos sistemas agrícolas. (Mestrado ), Universidade de São Paulo, Piracicaba, Piracicaba.

Rutherford, D. D., Burke, H. M., Cheung, K. K., \& Field, S. H. (2016). Impact of an Agricultural Value Chain Project on Smallholder Farmers, Households, and Children in Liberia. World Development, 83, 70-83. https://doi.org/10.1016/j.worlddev.2016.03.004

Salgado, R. J. d. S. F., \& Dias, M. M. (2013). Análise da influência do programa de aquisição de alimentos (PAA) sobre a qualidade de vida de agricultores familiares do município de Viçosa/MG. Perspectivas em Políticas Públicas, 6(11), 65-91.

Saraiva, E. B., da Silva, A. P., de Sousa, A. A., Cerqueira, G. F., Chagas, C. M., \& Toral, N. (2013). Panorama of purchasing food products from family farmers for the Brazilian School Nutrition Program. Cien Saude Colet, 18(4), 927-935. 10.1590/s1413-81232013000400004

Secretaria de Estado da Educação do Paraná (SEED/PR). Instrução Normativa 001/2014 - SUDE/DILOG/CANE. Instrui os Núcleos Regionais de Educação, Estabelecimentos de Ensino da Rede Estadual e Conveniados sobre a normatização e execução do Programa Estadual de Alimentação Escolar - PEAE e dá outras providências., IN 001/2014 C.F.R. (2014). Curitiba.

Silva, A. P. F. d., \& Sousa, A. A. d. (2013). Alimentos orgânicos da agricultura familiar no Programa Nacional de alimentação Escolar do Estado de Santa Catarina, Brasil. Revista de Nutrição, 26(6), 701-714. 10.1590/S1415-52732013000600009

Silverio, G. d. A., \& Sousa, A. A. d. (2014). Organic foods from family farms in the National School Food Program: Perspectives of social actors from Santa Catarina, Brazil. Revista de Nutrição, 27(3), 289-300. 10.1590/1415-52732014000300003

Sousa, A., Silva, A. P., Azevedo, E., \& Ramos, M. (2015). Cardápios e sustentabilidade: ensaio sobre as diretrizes do Programa Nacional de Alimentação Escolar. Revista de Nutrição, 28, 217-229. 10.1590/1415-52732015000200010 
Research, Society and Development, v. 10, n. 13, e88101321036, 2021

(CC BY 4.0) | ISSN 2525-3409 | DOI: http://dx.doi.org/10.33448/rsd-v10i13.21036

Souza-Esquerdo, V. F. d., \& Bergamasco, S. M. P. P. (2014). Análise sobre o acesso aos programas de políticas públicas da agricultura familiar nos municípios do circuito das frutas (SP). Revista de Economia e Sociologia Rural, 52(suppl 1), 205-222. 10.1590/S0103-20032014000600011

Stolarski, M. C. (2014). Pesquisa sobre o impacto das aquisições de alimentos da agricultura familiar para a alimentação escolar da rede de ensino público estadual do Paraná. Questionário de uso interno. . Curitiba.

Toyoyoshi, J., Oliveira, R., Santos, M., Galisa, M., \& Galante, A. (2013). Avaliação da aquisição de gêneros alimentícios provenientes da agricultura familiar para a alimentação escolar. O Mundo da Saúde, 37, 329-335. 10.15343/0104-7809.2013373329335

Triches, R. M., \& Schneider, S. (2010). Alimentação escolar e agricultura familiar: reconectando o consumo à produção. Saúde e Sociedade, 19(4), 933-945. $10.1590 /$ S0104-12902010000400019

Turpin, M. E. (2009). A alimentação escolar como fator de desenvolvimento local por meio do apoio aos agricultores familiares. Segurança Alimentar e Nutricional, Campinas, 16(2), 20-42.

Turpin, M. E. (2015). A alimentação escolar como fator de desenvolvimento local por meio do apoio aos agricultores familiares. Segurança Alimentar e Nutricional, 16(2), 20-42. 10.20396/san.v16i2.8634783

United Nations. (2021). Sustainable Development Goal. https://www.un.org/en/

Verano, T. d. C., Figueiredo, R. S., \& Medina, G. d. S. (2021). Agricultores familiares em canais curtos de comercialização: uma análise quantitativa das feiras municipais. Revista de Economia e Sociologia Rural, 59(3). 10.1590/1806-9479.2021.228830

Verano, T. d. C., \& Medina, G. (2021). Feiras que promovem a inclusão de agricultores familiares em cadeias curtas de comercialização. Estudos Sociedade e Agricultura, 29(1), 197-218. 10.36920/esa-v29n1-11

Vitte, C. d. C. S. (2006). Gestão do desenvolvimento econômico local: algumas considerações. Interações (Campo Grande), 8(13), 77-87. 10.1590/S151870122006000200009

Waltz, A. (2016). The women who feed us: Gender empowerment (or lack thereof) in rural Southern Brazil. Journal of Rural Studies, 47, 31-40. https://doi.org/10.1016/j.jrurstud.2016.07.009

Weber, J., \& Silva, T. N. d. (2021). A Produção Orgânica no Brasil sob a Ótica do Desenvolvimento Sustentável. Desenvolvimento em Questão, 19(54), 164184. $10.21527 / 2237-6453.2021 .54 .164-184$

WHO. (2002). Diet, nutrition and the prevention of chronic diseases: report of a joint WHO/FAO expert consultation; WHO. 